June 2019. Forthcoming in Social Science and Medicine.

\title{
CAN INEQUALITIES IN POLITICAL PARTICIPATION EXPLAIN HEALTH INEQUALITIES?*
}

\author{
Aaron Reeves ${ }^{\dagger}$ and Johan P. Mackenbach ${ }^{\ddagger}$
}

June 15, 2019

\begin{abstract}
:
Inequalities in health are pervasive and durable, but they are not uniform. To date, however, the drivers of these between-country patters in health inequalities remain largely unknown. In this analysis, we draw on data from 17 European countries to explore whether inequalities in political participation, that is, inequalities in voting by educational attainment, are correlated with health inequalities. Over and above a range of relevant confounders, such as GDP, income inequality, health spending, social protection spending, poverty rates, and smoking, greater inequalities in political participation remain correlated with higher health inequalities. If 'politicians and officials are under no compulsion to pay much heed to classes and groups of citizens that do not vote' then political inequalities could indirectly affect health through its impact on policy choices that determine who has access to the resources necessary for a healthy life. Inequalities in political participation, then, may well be one of the 'causes of the causes' of ill-health.
\end{abstract}

\section{INTRODUCTION}

Inequalities in health are pervasive and durable, but they are not uniform.[1,2] Relative inequalities in male mortality by educational attainment are low in Spain, Italy, and Belgium (Ratio Ratios 1.5-1.6) and high in the Czech Republic, Hungary, and Lithuania (Rate Ratios >2.5). [3] Health inequalities are also observed across a range of health outcomes, including tobaccorelated deaths, obesity, and even self-assessed health.[4-6] Yet, one of the great disappointments of public health is that these health inequalities persist in high-income countries despite substantial improvement in living standards, the creation of welfare states, and concerted government efforts to reduce such disparities.[7,8] Until recently, data limitations have made it

\footnotetext{
*Replication materials are available here: https://github.com/asreeves/political-inequality-health-inequality

${ }^{\dagger}$ University of Oxford, aaron.reeves@spi.ox.ac.uk

${ }^{\ddagger}$ Erasmus MC, $j$.mackenbach@erasmusmc.nl
} 
difficult to examine why 'inequalities in mortality are larger in some European countries than in others' and so the drivers of these between-country patters remain 'largely unknown'.[3]

The unequal distribution of the social determinants of health (such as income) $[9,10]$ will be part of the explanation, but this does not explain why the social determinants of health are unequally distributed.[8,11] To understand this, researchers must look beyond the proximal causes of illhealth to those institutions that structure who gets access to health-enhancing resources, the so-called 'causes of the causes'.[10,12] For example, inequalities in political participation, such as differences between social groups in voter turnout $[13,14]$, letter writing, and donating to campaigns [15], may have especially profound implications for health inequalities precisely because such actions potentially shape the social determinants of health.

Inequalities in political participation affect manifestos, policy decisions, and who has the power to govern.[16,17] Voter turnout, which is the focus of this study, is a highly salient form of political participation because political parties in democracies win elections by appealing to those who will put them power, that is, the people who actually show up at the ballot box.[18] This can be problematic because the better educated vote more often than the less educated $[16,19-21]$ and so the interests of these under-represented groups may often be overlooked in the creation of policy.[22,23] Those with high-levels and low-levels of education are not necessarily opposed in policy terms but empirically their preferences do often pull in different directions.[24,25] That is, educational qualifications do not perfectly determine policy preferences but, on average, there are clear differences between highly educated voters and those with less education, even within the same party. The British Labour Party has high level of support among both highly educated voters and voters with little education.[26] These groups do not always agree, however, and this is particularly clear on the issue of Brexit but also shows up on other issues like tuition fees for university education [27].

One explanation for these differences stresses the centrality of 'material gains... through [both] the market and the state' to political preferences. People 'tend to opt for markets when their endowments and capabilities expect strong market revenues' [24] and so highly educated voters, especially in a period of skill-biased technical change [28], have strong reasons to favour policies which enhance markets. It is in this economic context, that education has certainly become a primary political cleavage in most European countries [25,29]. As Iversen and Soskice have recently argued: 'the rising educated middle classes may have little interest in redistribution to the poor because they are themselves relatively secure' [25].

The declining influence of voters with little education could also simultaneously increase the influence of powerful vested interests who frequently seem to deploy their resources to achieve concrete political ends which are against the interests of these precarious communities.[30,31] Politicians are not so ideologically flexible that they can sell their preferences to the highest bidder [32] but money can influence policy positions [33] and, perhaps more importantly, it shapes who wins elections.[34] Donors, then, have the ability to boost their preferred nominees and thereby suppressing some candidates from ever reaching office.[34] While political institutions shape the set of policy options included in manifestoes [35], declining turnout among poorer voters may still affect who is elected,[16] giving an advantage to politicians whose policies are 
less aligned with the interests and preferences of people with less formal education.[20]

When policies, platforms, and politicians predominantly speak to those who vote, then inequalities in voting may translate into inequalities in health.[36] Quite simply, votes affect policy and policy affects health.[37,38] Declining turnout among people with less education may reduce government spending on social protection [20,39-41], and cuts to social protection may affect health.[37,42-45] Lower turnout in general is associated with higher mortality rates [36] and individuals living in US states with higher voter inequality had, on average, poorer selfreported health.[46] These policies are especially likely to affect health inequalities - particularly relative inequalities - because they are policies which predominantly affect the poorest. Inequalities in political participation, then, create a situation in which pro-poor policies are less likely and this may affect health inequalities.

\section{DATA AND METHOD}

To date, limited data on health inequalities across countries has meant it is difficult to address whether inequalities in political participation are correlated with health inequalities. This is the question we explore here. To do so, we merged the DEMETRIQ project's estimates of health inequalities (mostly mid-2000s) by education in 17 European countries (Austria, Belgium, the Czech Republic, Denmark, England/Wales, Estonia, Finland, France, Hungary, Italy, Lithuania, Norway, Poland, Slovenia, Spain, Sweden, and Switzerland) with other countrylevel data.[4,47] Measures of relative inequalities include all-cause mortality (the main outcome of interest) and also cause-specific inequalities: cancer mortality, cardiovascular disease mortality, other diseases, and external causes for both men and women. These data are drawn from register-based mortality data. Relative inequalities are calculated as the Rate Ratio (RR) of age-standardized mortality among 'low' as compared to 'high' educated. The data on health inequalities is then compared to inequalities in political participation: the percentage point gap in voting between those who have tertiary education and those who have a secondary education or less. These data are taken from wave 4 of the European Social Survey (collected between 2007 and 2008), with one exception: data is from wave 2 for Italy (collected 2003 and 2004). Education is a particularly useful measure of inequalities in political participation because it has a clear causal relationship with voter turnout and is a common method of calculating health inequalities.[48] We also collect data on inequalities in poverty risk and smoking (for men and women) from Eurostat as well as other macroeconomic indicators, such as GDP, the GINI coefficient, social protection spending, and health spending (see Web Appendix 1 for full details).

We calculate both the raw association between inequalities in political participation and health inequality and we also test whether this association changes when we account for confounders. We also calculate these same associations for inequalities in cause-specific mortality across this same set of countries. 


\section{ARE INEQUALITIES IN POLITICAL PARTICIPATION CORRELATED WITH HEALTH INEQUALITIES?}

Figures 1 and 2 show the bivariate relationship between inequalities in political participation and health inequalities. In both cases, inequalities in political participation are highly correlated with health inequalities in all-cause mortality for men $(r=0.7354, \mathrm{p}=0.001)$ and women $(r=0.6296, \mathrm{p}=0.007)$. We test the sensitivity of these correlation coefficients to outliers by estimating 17 separate regression models which sequentially drop one country at a time to see whether the overall relationship changes (see Web Appendix 2). We find that the association reported is consistent irrespective of whether any specific country is removed from the analysis.

What is the magnitude of this association (see Table 1: Column 1; Table 2: Column 1)? A 1 percentage point reduction in the gap in voting between high and low educated people would reduce the Rate Ratio in educational inequality in all-cause male mortality by 0.13 (95\% CI: 0.085 to 0.168 ). In other words, assuming this relationship is causal, if Lithuania reduced their political inequality in voting to the level of Denmark then Lithuania would have approximately the same level of male health inequality as Denmark.

\section{CAN THIS CORRELATION BE EXPLAINED BY OTHER FACTORS?}

While plausible, the large association implies other factors may confound the raw correlation between political and health inequalities. Therefore, like Mackenbach and colleagues [3], we estimate multivariate linear regression models with the Rate Ratio of educational inequality as the dependent variable, inequalities in political participation as the primary independent variable, and a series of potentially confounding variables to test these alternative explanations.

Seven possible confounding variables are examined here, all of which have been proposed as causes of health inequalities and may be correlated with inequalities in voting: 1) GDP;2) Income inequality (the GINI coefficient); 3) Social protection spending per capita; 4) Postcommunist countries; 5) Total health spending (\% GDP); 6) Poverty rates by education, and 7) Differences in smoking rates by education. Details for all variables are in web appendix 1.

None of these potential confounders removes the association between inequalities in political participation and health inequalities for men or for women. In fact, in most cases, these variables are not directly correlated with relative health inequalities after accounting for inequalities in political participation.

Even when we adjust for all of these variables at the same time, we still find that inequalities in political participation remain closely associated with health inequalities (see Table 1: Column 9; Table 2: Column 9). This finding is surprising given (1) the small number of observations, (2) that previous work has found that some of these measures are correlated with health inequalities, and (3) that some of these variables are possible albeit imperfect mediators, such as social protection spending.[49] 
Figure 1: Inequalities in political participation and educational inequalities in health among men

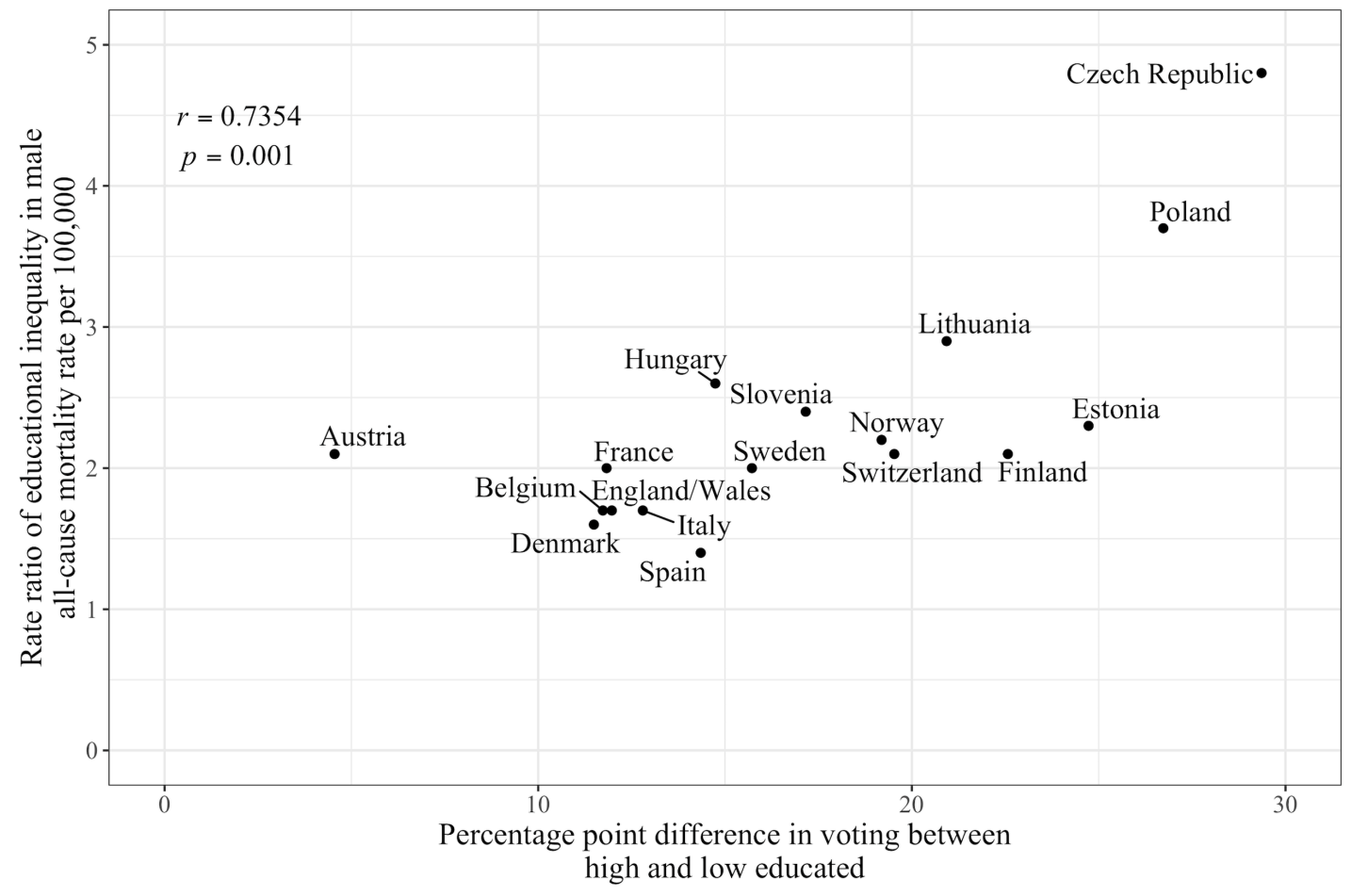

Figure 2: Inequalities in political participation and educational inequalities in health among women

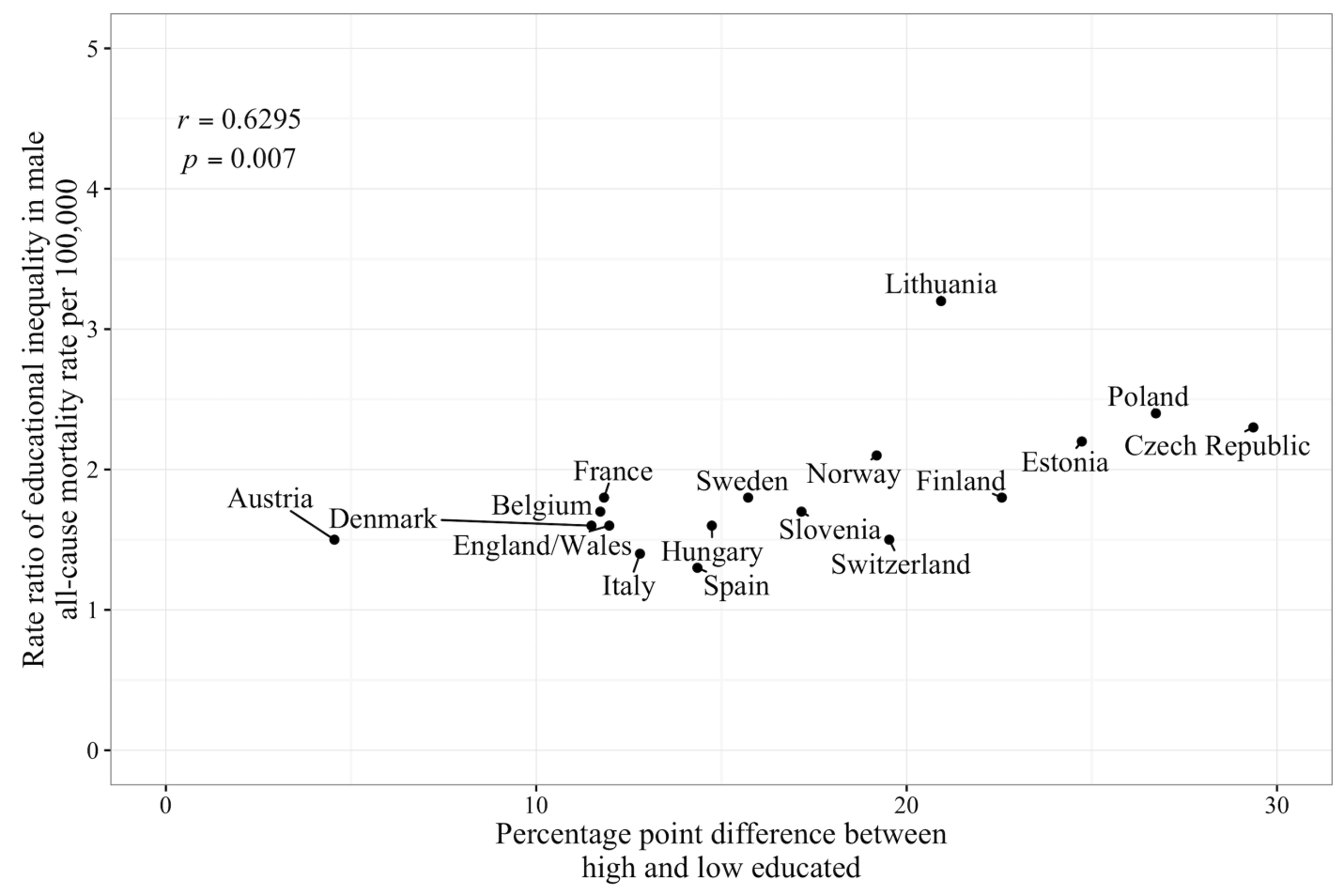


Table 1: Inequalities in political participation and educational inequalities in health among men adjusted for covariates

Rate ratio for educational health inequality in male all-cause mortality

\begin{tabular}{|c|c|c|c|c|c|c|c|c|c|}
\hline & (1) & (2) & (3) & (4) & (5) & (6) & (7) & (8) & (9) \\
\hline \multirow[t]{2}{*}{ Percentage point difference in voting by education } & $0.13^{* *}$ & $0.12^{* *}$ & $0.13^{* *}$ & $0.13^{* *}$ & $0.12^{* *}$ & $0.16^{* *}$ & $0.11^{* *}$ & $0.13^{* *}$ & $0.11^{* *}$ \\
\hline & $(0.019)$ & $(0.026)$ & $(0.016)$ & $(0.033)$ & $(0.021)$ & $(0.024)$ & $(0.029)$ & $(0.020)$ & $(0.028)$ \\
\hline \multirow[t]{2}{*}{ GDP per capita, adjusted for purchasing power parity } & & -0.00088 & & & & & & & 0.00044 \\
\hline & & $(0.00082)$ & & & & & & & $(0.00092)$ \\
\hline \multirow[t]{2}{*}{ GINI $(0$ = perfect equality $)$} & & & -0.063 & & & & & & -0.12 \\
\hline & & & $(0.032)$ & & & & & & $(0.056)$ \\
\hline \multirow[t]{2}{*}{ Social protection spending } & & & & -0.00021 & & & & & -0.0020 \\
\hline & & & & $(0.0059)$ & & & & & $(0.0052)$ \\
\hline \multirow[t]{2}{*}{ Post-communist countries $(=1)$} & & & & & $0.59^{*}$ & & & & 0.32 \\
\hline & & & & & $(0.27)$ & & & & $(0.36)$ \\
\hline \multirow[t]{2}{*}{ Health expenditure (\% of GDP) } & & & & & & $0.25^{*}$ & & & 0.12 \\
\hline & & & & & & $(0.10)$ & & & $(0.086)$ \\
\hline Difference in the proportion of the population & & & & & & & 0.016 & & $0.064^{*}$ \\
\hline at risk of poverty by education & & & & & & & $(0.020)$ & & $(0.021)$ \\
\hline Difference in the proportion of the population who & & & & & & & & -0.0048 & 0.018 \\
\hline are current smokers by education & & & & & & & & $(0.016)$ & $(0.014)$ \\
\hline Observations & 17 & 17 & 17 & 17 & 17 & 17 & 17 & 17 & 17 \\
\hline$R^{2}$ & 0.75 & 0.76 & 0.80 & 0.75 & 0.79 & 0.82 & 0.77 & 0.76 & 0.94 \\
\hline
\end{tabular}

Notes: ${ }^{*} \mathrm{p}<0.05,{ }^{* *} \mathrm{p}<0.01$. Standard errors in parentheses. All models are weighted by population size. Constant estimated but not reported. See web appendix 1 for more details on covariates. 
Table 2: Inequalities in political participation and educational inequalities in health among women adjusted for covariates

\begin{tabular}{|c|c|c|c|c|c|c|c|c|c|}
\hline & \multicolumn{9}{|c|}{ Rate ratio for educational health inequality in female all-cause mortality } \\
\hline & (1) & $(2)$ & (3) & (4) & $(5)$ & $(6)$ & $(7)$ & $(8)$ & $(9)$ \\
\hline \multirow[t]{2}{*}{ Percentage point difference in voting by education } & $0.049^{* *}$ & $0.047^{* *}$ & $0.052^{* *}$ & $0.058^{* *}$ & $0.047^{* *}$ & $0.067^{* *}$ & $0.041^{* *}$ & $0.048^{* *}$ & $0.057^{* *}$ \\
\hline & $(0.0093)$ & $(0.012)$ & $(0.011)$ & $(0.016)$ & $(0.011)$ & $(0.015)$ & $(0.0067)$ & $(0.0096)$ & $(0.013)$ \\
\hline \multirow[t]{2}{*}{ GDP per capita, adjusted for purchasing power parity } & & -0.00013 & & & & & & & -0.00056 \\
\hline & & $(0.00057)$ & & & & & & & $(0.00058)$ \\
\hline \multirow[t]{2}{*}{ GINI ( 0 = perfect equality) } & & & -0.026 & & & & & & -0.047 \\
\hline & & & $(0.021)$ & & & & & & $(0.032)$ \\
\hline \multirow[t]{2}{*}{ Social protection spending } & & & & 0.0023 & & & & & 0.012 \\
\hline & & & & $(0.0035)$ & & & & & $(0.0060)$ \\
\hline \multirow[t]{2}{*}{ Post-communist countries $(=1)$} & & & & & 0.099 & & & & 0.34 \\
\hline & & & & & $(0.22)$ & & & & $(0.39)$ \\
\hline \multirow[t]{2}{*}{ Health expenditure (\% of GDP) } & & & & & & 0.13 & & & 0.045 \\
\hline & & & & & & $(0.070)$ & & & $(0.064)$ \\
\hline Difference in the proportion of the population & & & & & & & 0.011 & & $0.057^{*}$ \\
\hline at risk of poverty by education & & & & & & & $(0.011)$ & & $(0.018)$ \\
\hline Difference in the proportion of the population who & & & & & & & & -0.0040 & 0.035 \\
\hline are current smokers by education & & & & & & & & $(0.013)$ & $(0.019)$ \\
\hline Observations & 17 & 17 & 17 & 17 & 17 & 17 & 17 & 17 & 17 \\
\hline$R^{2}$ & 0.54 & 0.54 & 0.58 & 0.56 & 0.55 & 0.63 & 0.57 & 0.55 & 0.87 \\
\hline
\end{tabular}

Notes: ${ }^{*} \mathrm{p}<0.05,{ }^{* *} \mathrm{p}<0.01$. Standard errors in parentheses. All models are weighted by population size. Constant estimated but not reported. See web appendix 1 for more details on covariates. 
Figure 3: Inequalities in political participation and educational inequalities in cause-specific mortality among men adjusted for covariates

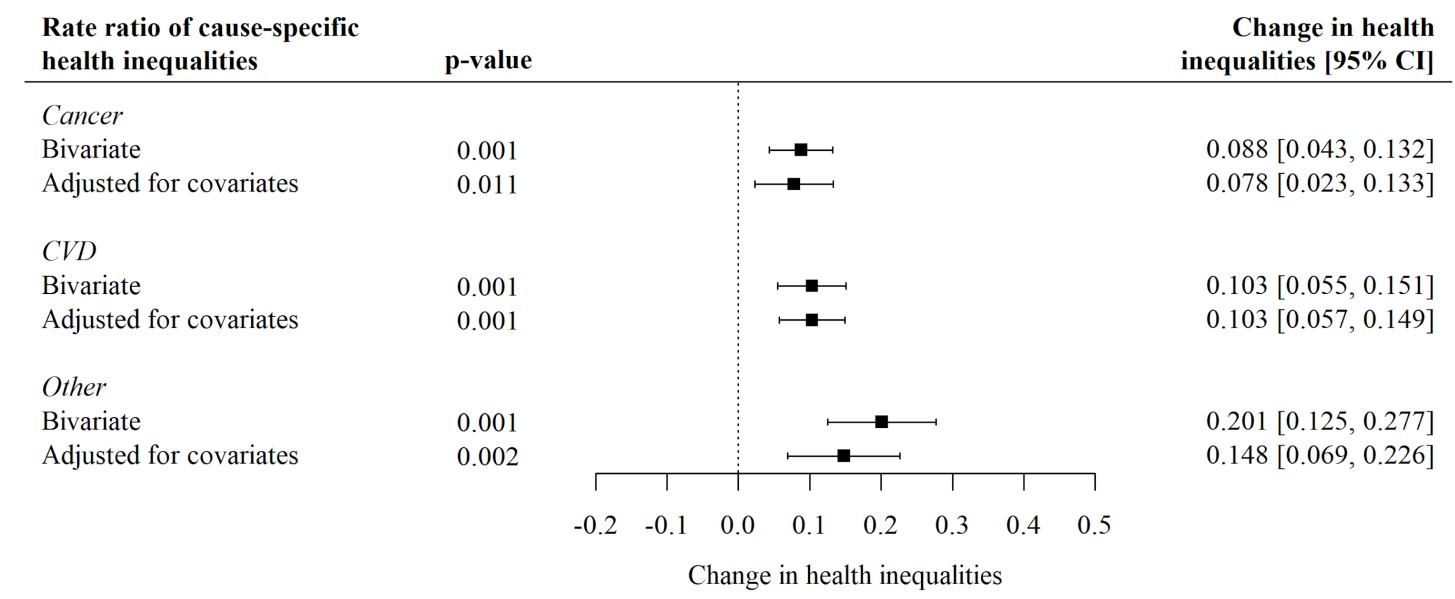

Notes: All models weight for population. See web appendix 1 for more details on covariates.

Figure 4: Inequalities in political participation and educational inequalities in cause-specific mortality among women adjusted for covariates

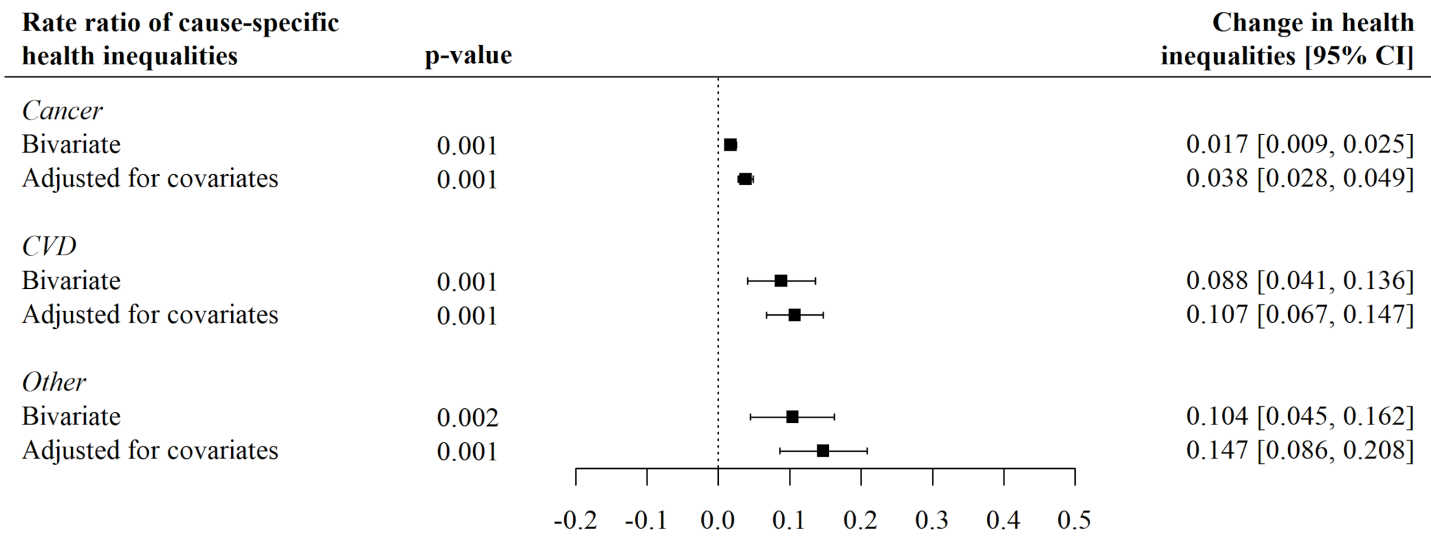

Change in health inequalities

Notes: All models weight for population. See web appendix 1 for more details on covariates. 


\section{ARE INEQUALITIES IN POLITICAL PARTICIPATION CORRELATED WITH CAUSE-SPECIFIC MORTALITY RATES?}

Health inequalities data are available for three main outcomes: cancers, cardiovascular diseases, and other causes. Together these constitute the primary causes of death in most highincome countries and therefore represent those areas where health inequalities have the largest impact on all-cause mortality.

In figures 3 and 4 we report the coefficients of the relationship between political and health inequalities for each of the Rate Ratios by education of these cause-specific mortality rates. We also show the same coefficient after adjusting for the same variables described above.

In every case, health inequalities by education are higher in countries where there are larger inequalities in political participation, and these relationships remain even when adjusting for all of these confounders at the same time.

Viewed together, these results indicate that inequalities in political participation are strongly correlated with each of the main drivers of health inequalities in the population at large and that this is not driven by one particular type of mortality.

\section{INEQUALITIES IN POLITICAL PARTICIPATION: 'A CAUSE OF THE CAUSES'}

Inequalities in political participation are correlated with health inequalities but they are unlikely to be the direct cause of differences in mortality between people with high and low levels of education. Rather, if inequalities in political participation affect health at all it will be an indirect causal effect through the impact of voting inequalities on policy choices that determine who has access to the resources necessary for a healthy life.

The uncomfortable truth is that politicians and officials are under no compulsion to pay much heed to classes and groups of citizens that do not vote'.[50] Growing inequalities in political participation in voting therefore could potentially explain why societies have failed to make more progress in addressing relative health inequalities: the people with the poorest health are also the least likely to vote.

Consider the UK. In 2010, amidst the Great Recession, the British people elected a coalition government planning to implement austerity policies aimed at reducing welfare spending. Turn out in this election was 9 percentage points lower than it had been when it elected New Labour in 1997. Moreover, the gap in voting between the most and the least affluent had increased 6 percentage points from 13\% in 1997 to $19 \%$ in 2010, an almost 50\% increase. The subsequent cuts fell on the poorest parts of the country [51] and now, following a period when health inequalities seemed to narrow, they have begun widening slightly again.[52]

But this problem goes far beyond the UK alone. Many countries are currently facing demo- 
cratic crises and these periods of political uncertainty may only make things worse. Voter turnout has been declining steadily in most high-income countries since the early 1980s, particularly among those with less education. At the same time, the political influence of the richest $1 \%$ has expanded in tandem with their growing wealth, with campaign contributions in the US increasingly dominated by the very richest Americans $(0.01 \%$ of the income distribution).[53] Economics elites are now able to donate even more to politicians willing to cut taxes or introduce amendments that align with their priorities.

Brexit, Trump and other manifestations of populist voting may, at first glance, seem like counterpoints because these electoral outcomes are often represented as instances of people with less education seemingly voting against their interests. If this is true then inequalities in political participation may actually benefit health if people with less education who vote against their interests have less power. Certainly, populism reveals that economics are not the only salient factor in determining vote choice; religion, culture, and identity also matter.[54] But whether Brexit voters, for example, are indeed voting against their interests is highly contested.[55] Economic change over the last few decades has blocked some groups from 'experiencing upward mobility' - that is, from ensuring a better life for their children - and these voters have 'tend[ed] to react politically against the system' by voting for individuals or groups who reject the dominant frame for political debate within a country context.[25,56] These economic barriers to mobility are keenly felt among the so-called 'losers' of advanced capitalism (that is, the old middle-classes, particularly those who did not attend university) and they were always a little less sympathetic to redistribution. When they cast their votes for a return to the old economic order, they are voting for an improvement in their economic position and so are less concerned about cuts to welfare or even tax cuts for the rich. The rise of populism then is a product of the declining fortunes and the steady disenfranchisement of some groups in highincome societies which may have, in turn, contributed to rising mortality rates in some of these groups and the stagnation of health inequalities over this same period.[57] Just as the current challenge to democratic societies is a response to decades of policy choices, so too health inequalities may be the product of many decisions made by successive governments seeking to appeal to steadily more skilled voters who are the beneficiaries of advanced capitalism.

Of course, while provocative, this is not the only line of reasoning consistent with our results. We cannot rule out, for example, the possibility that both health inequalities and inequalities in political participation share a common underlying cause not accounted for in our models above. For example, the structural disadvantage faced by groups with less education may lead them to feel alienated from the mainstream in their country and may then be both less inclined to vote and to experience poorer health.[58] Of course, it is also possible that health inequalities are the cause of inequalities in voter turnout too.[59] For example, the dire health situation among the low educated in Central \& Eastern Europe may have increased the costs of participating in political processes. Our results, then, may point toward a causal relationship between inequalities in political participation and health inequalities,[30] but far more research is needed on whether inequalities in political participation do, in fact, lead to policies that are detrimental to health inequalities.

Another complexity is that the political preferences of citizens are not the only driver of policy 
choices (the demand-side of politics). Political institutions constrain who has power to make policy proposals (the supply-side of politics).[24,60] Democratic institutions, for example, may benefit health precisely because they shift the supply-side of politics by creating an open and competitive mechanism through which potential leaders can offer policies to voters.[61] In theory, pro-poor politicians are more likely to enter elections in democracies, and they are more likely to win. But democratic institutions are not all alike, and some political arrangements, such as proportional representation, more consistently deliver pro-poor policies, including better health,[62] than other forms of democracy, irrespective of the preferences of voters.[35]

However, in democracies of all kinds, policy change is always difficult because the legacies of previous decisions limit the set of possible choices available to politicians in the present.[24] It is no small thing to radically reorganise healthcare systems or to fundamentally alter the principles undergirding social security systems, and this is why such efforts have often failed.[63-65] Indeed, the institutional inertia slowing down such change is the reason radical reforms have been most successful in response to crises which seemingly weaken the hold of pre-existing institutions on society.[66,67] Democracies do not guarantee that popular, health-enhancing policies with support from politicians will be enacted.

One important gap in our analysis is that inequalities in political participation and inequalities in health are not just structured by education, they also occur across genders and along racial and ethnic lines.[54] Indeed the intersection of these identities may create particular policy blind-spots which leave certain groups, perhaps Black, low-educated women, at a particular disadvantage.[68] The inclusion of women, for example, in decision-making processes seems to have influenced policy decisions and also health, $[69,70]$ and the same appears to be true for racial minorities, in the U.S. at least.[71] But, more work is needed on how political inequalities across these identities affect who has voice and, in turn, how this may affect health.

When Theresa May stood on the steps of 10 Downing Street shortly after becoming Prime Minister, health inequalities was first on her list of 'burning injustices' that needed to be tackled.[72] But fighting against these injustices requires more than simply announcing that governments will not be driven 'by the interests of the privileged few' because it is incredibly difficult to avoid 'entrench[ing] the advantages of the fortunate' when they vote for your party and form a large share of your party's constituents. Rather, reversing health inequalities may require a dramatic deepening of democratic institutions that minimises inequalities in political participation as a means of addressing other forms of social inequality.[73] Deepening democracy, however, is more than simply increasing voter turnout but instead implies more fundamental changes to our political institutions, changes which stop privileging the voices of the affluent over the materially deprived. If this view is right, inequalities in political participation, then, may be one of the 'causes of the causes' of ill-health. 
Acknowledgments We would like to thank Rachel Loopstra for helpful comments on earlier versions of this paper. We would also like to acknowledge the reviewers and the editor at Social Science and Medicine whose comments have helped improve the paper.

Funding Supported by a grant (FP7-CP-FP Grant no. 278511) from the European Commission Research and Innovation Directorate General, as part of the "Developing methodologies to reduce inequalities in the determinants of health" (DEMETRIQ) project. The sponsor had no role in the study design; in the collection, analysis, and interpretation of data; in the writing of the report; and in the decision to submit the article for publication.

Supported by the Joseph Rowntree Foundation. The sponsor had no role in the study design; in the collection, analysis, and interpretation of data; in the writing of the report; and in the decision to submit the article for publication.

Aaron Reeves is Associate Professor in the Department of Social Policy and Intervention at the University of Oxford. His research is focused on understanding the causes and consequences of social, economic, and cultural inequality across countries.

Johan P. Mackenbach is Professor of Public Health and chair of the Department of Public Health at Erasmus MC, University Medical Center Rotterdam, the Netherlands. His research interests are in social epidemiology, medical demography, and health policy. He has (co-)authored more than 500 papers in international, peer-reviewed scientific journals, as well as a number of books. 


\section{REFERENCES}

1 Mackenbach JP. Nordic paradox, Southern miracle, Eastern disaster: persistence of inequalities in mortality in Europe. Eur J Public Health 2017;27:14-7.

2 Reeves A. Commentary: Uncertainties in addressing the 'health gap'. Int J Epidemiol 2017; 46: $1324-8$.

3 Mackenbach JP, Bopp M, Deboosere P, et al. Determinants of the magnitude of socioeconomic inequalities in mortality: A study of 17 European countries. Health Place 2017;47:4453.

4 Hu Y, Lenthe FJ van, Borsboom GJ, et al. Trends in socioeconomic inequalities in self-assessed health in 17 European countries between 1990 and 2010. J Epidemiol Community Health 2016;70:644-52.

5 Hoffmann K, De Gelder R, Hu Y, et al. Trends in educational inequalities in obesity in 15 European countries between 1990 and 2010. Int J Behav Nutr Phys Act 2017;14:63.

6 Gregoraci G, Lenthe FJ van, Artnik B, et al. Contribution of smoking to socioeconomic inequalities in mortality: a study of 14 European countries, 1990-2004. Tob Control 2017;26:2608.

7 Hu Y, van Lenthe FJ, Judge K, et al. Did the English strategy reduce inequalities in health? A difference-in-difference analysis comparing England with three other European countries. BMC Public Health 2016;16.

8 Mackenbach JP. The persistence of health inequalities in modern welfare states: The explanation of a paradox. Soc Sci Med 2012;75:761-9.

9 Marmot M. The Health Gap: The Challenge of an Unequal World. 1st ed. Bloomsbury 2015.

10 Marmot M. Social determinants of health inequalities. The Lancet 2005;365:1099-104.

11 Beckfield J, Bambra C, Eikemo TA, et al. An institutional theory of welfare state effects on the distribution of population health. Soc Theory Health 2015;13:227-44.

12 Rose G. The Strategy of Preventive Medicine. New edition edition. Oxford: : OUP Oxford 1993.

13 Armingeon K, Schädel L. Social Inequality in Political Participation: The Dark Sides of Individualisation. West Eur Polit 2015;38:1-27.

14 Solt F. Economic Inequality and Democratic Political Engagement. Am J Polit Sci 2008; 52: 48-60. 
15 Marien S, Hooghe M, Quintelier E. Inequalities in Non-Institutionalised forms of Political Participation: A Multi-Level Analysis of 25 Countries. Polit Stud 2010;58:187-213.

16 Lijphart A. Unequal Participation: Democracy’s Unresolved Dilemma. Am Polit Sci Rev 1997;91:1-14.

17 Hill KQ, Leighley JE. The Policy Consequences of Class Bias in State Electorates. Am J Polit Sci 1992;36:351-65.

18 Meltzer AH, Richards SF. A rational theory of the size of government. J Polit Econ 1981; 89: 914-27.

19 Lipset SM. Political Man: The Social Bases of Politics. Johns Hopkins University Press 1981.

20 Fowler A. Electoral and Policy Consequences of Voter Turnout: Evidence from Compulsory Voting in Australia. QJ Polit Sci 2013;8:159-82.

21 Smets K, Van Ham C. The embarrassment of riches? A meta-analysis of individual-level research on voter turnout. Elect Stud 2013;32:344-359.

22 Fowler A. Regular Voters, Marginal Voters and the Electoral Effects of Turnout. Polit Sci Res Methods 2015;3:205-19.

23 Geys B. Explaining voter turnout: A review of aggregate-level research. Elect Stud 2006;25:63763.

24 Beramendi P, Häusermann S, Kitschelt $\mathrm{H}$, et al. Introduction: The Politics of Advanced Capitalism. In: Beramendi P, Hausermann S, Kitschelt H, et al., eds. The Politics of Advanced Capitalism. Cambridge: : Cambridge University Press 2015. 1-64.

25 Iversen T, Soskice D. Democracy and Prosperity: The Reinvention of Capitalism in a Turbulent Century. Princeton, NJ: : Princeton University Press 2019.

26 Tilley J, Evans G. The New Politics of Class after the 2017 General Election. Polit Q 2017; 88: $710-5$.

27 Quinn T. Behind the Brexit vote, Labour remains dangerously divided. The Conversation. 2019.http://theconversation.com/behind-the-brexit-vote-labour-remains-dangerously-divided103899 (accessed 11 Jun 2019).

28 Goldin CD, Katz LF. The Race Between Education and Technology. Harvard University Press 2008.

29 Bovens M, Wille A. Diploma Democracy: The Rise of Political Meritocracy. Oxford, New York: : Oxford University Press 2017. 
30 Page BI, Gilens M. Testing Theories of American Politics: Elites, Interest Groups, and Average Citizens. Perspect Polit 2014;12:564-81.

31 Hacker JS, Pierson P. Winner-take-all politics : how Washington made the rich richer-and turned its back on the middle class. New York: Simon \& Schuster 2010.

32 Ansolabehere S, de Figueiredo JM, Snyder JM. Why Is There so Little Money in U.S. Politics? J Econ Perspect 2003;17:105-30.

33 Fellowes MC, Wolf PJ. Funding Mechanisms and Policy Instruments: How Business Campaign Contributions Influence Congressional Votes. Polit Res Q 2004;57:315-24.

34 Abramowitz AI. Incumbency, Campaign Spending, and the Decline of Competition in U.S. House Elections. J Polit 1991;53:34-56.

35 Iversen T, Soskice D. Electoral Institutions and the Politics of Coalitions: Why Some Democracies Redistribute More than Others. Am Polit Sci Rev 2006;100:165-81.

36 Chung H, Muntaner C. Political and welfare state determinants of infant and child health indicators: An analysis of wealthy countries. Soc Sci Med 2006;63:829-42.

37 Reeves A, Clair A, McKee M, et al. Reductions in the United Kingdom's Government Housing Benefit and Symptoms of Depression in Low-Income Households. Am J Epidemiol 2016; 184: 421-9.

38 Lundberg O, Yngwe MA, Stjarne MK, et al. The role of welfare state principles and generosity in social policy programmes for public health: an international comparative study. Lancet 2008;372:1633-40.

39 Pontusson J, Rueda D. The Politics of Inequality: Voter Mobilization and Left Parties in Advanced Industrial States. Comp Polit Stud 2010;43:675-705.

40 Husted TA, Kenny LW. The Effect of the Expansion of the Voting Franchise on the Size of Government. J Polit Econ 1997;105:54-82.

41 Lott Jr John R, Kenny LW. Did Women's Suffrage Change the Size and Scope of Government? J Polit Econ 1999;107:1163-98.

42 Stuckler D, Basu S, McKee M. Budget crises, health, and social welfare programmes. Br Med J 2010;340.

43 Reeves A, Basu S, McKee M, et al. Social protection and tuberculosis control in 21 European countries, 1995-2012: a cross-national statistical modelling analysis. Lancet Infect Dis 2014;14:1105-12. 
44 Reeves A, McKee M, Mackenbach J, et al. Public pensions and unmet medical need among older people: cross-national analysis of 16 European countries, 2004-2010. J Epidemiol Community Health 2017;71:174-80.

45 Duflo E. Child health and household resources in South Africa: Evidence from the Old Age Pension program. Am Econ Rev 2000;90:393-8.

46 Blakely TA, Kennedy BP, Kawachi I. Socioeconomic inequality in voting participation and self-rated health. Am J Public Health 2001;91:99-104.

47 Mackenbach JP, Kulhánová I, Artnik B, et al. Changes in mortality inequalities over two decades: register based study of European countries. BMJ 2016;353:i1732.

48 Sondheimer RM, Green DP. Using Experiments to Estimate the Effects of Education on Voter Turnout. Am J Polit Sci 2010;54:174-89.

49 Acharya A, Blackwell M, Sen M. Explaining Causal Findings Without Bias: Detecting and Assessing Direct Effects. Am Polit Sci Rev 2016;110:512-29.

50 Key VO, Heard A. Southern Politics in State and Nation. University of Tennessee Press 1949.

51 Beatty C, Fothergill S. Hitting the Poorest Places Hardest: The local and regional impact of welfare reform. Sheffield: : Sheffield Hallam University 2013.

52 Barr B, Higgerson J, Whitehead M. Investigating the impact of the English health inequalities strategy: time trend analysis. BMJ 2017;358:j3310.

53 Bonica A, McCarty N, Poole KT, et al. Why Hasn't Democracy Slowed Rising Inequality? J Econ Perspect 2013;27:103-24.

54 Norris P, Inglehart R. Cultural Backlash and the Rise of Populism: Trump, Brexit, and Authoritarian Populism. Cambridge University Press 2019.

55 Roger E, Goodwin M. National Populism: The Revolt Against Liberal Democracy. London: : Pelican 2018.

56 Glas JM, Richey S, Taylor JB, et al. Polls and Elections: There Is Nothing Wrong with Kansas: The Effect of Race and Economics on Voting Correctly in U.S. Presidential Elections. Pres Stud Q 2016;46:158-72.

57 Case A, Deaton A. Mortality and morbidity in the 21st century. Brook Pap Econ Act; 2017: 397.

58 Holman D, Walker A. Social Quality and Health: Examining Individual and Neighbourhood 
Contextual Effects Using a Multilevel Modelling Approach. Soc Indic Res 2018;138:245-270.

59 Mattila M, Söderlund P, Wass H, et al. Healthy voting: The effect of self-reported health on turnout in 30 countries. Elect Stud 2013;32:886-91.

60 Lynch J. Age in the Welfare State: The Origins of Social Spending on Pensioners, Workers, and Children. Cambridge University Press 2006.

61 Bollyky TJ, Templin T, Cohen M, et al. The relationships between democratic experience, adult health, and cause-specific mortality in 170 countries between 1980 and 2016: an observational analysis. The Lancet 2019;0.

62 Wigley S, Akkoyunlu-Wigley A. Do electoral institutions have an impact on population health? Public Choice 2011;148:595-610.

63 Pierson P. Dismantling the welfare state? : Reagan, Thatcher, and the politics of retrenchment. Cambridge: : Cambridge University Press 1994.

64 Hacker JS, Pierson P. The Dog That Almost Barked: What the ACA Repeal Fight Says about the Resilience of the American Welfare State. J Health Polit Policy Law 2018;43:551-77.

65 Hacker JS. The Road to Nowhere: The Genesis of President Clinton's Plan for Health Security. Princeton University Press 1999.

66 Piketty T. Capital in the Twenty-First Century. Cambridge Massachusetts: : Harvard University Press 2014.

67 Scheidel W. The Great Leveler: Violence and the History of Inequality from the Stone Age to the Twenty-First Century. Princeton, New Jersey: : Princeton University Press 2017.

68 Bowleg L. The Problem With the Phrase Women and Minorities: Intersectionality-an Important Theoretical Framework for Public Health. Am J Public Health 2012;102:1267-73.

69 Chattopadhyay R, Duflo E. Women as Policy Makers: Evidence from a Randomized Policy Experiment in India. Econometrica 2004;72:1409-43.

70 Quamruzzaman A, Lange M. Female political representation and child health: Evidence from a multilevel analysis. Soc Sci Med 2016;171:48-57.

71 Krieger N, Kosheleva A, Waterman PD, et al. 50-year trends in US socioeconomic inequalities in health: US-born Black and White Americans, 1959-2008. Int J Epidemiol Published Online First: 16 March 2014.

72 Statement from the new Prime Minister Theresa May, Prime Minister's Office. 10 Downing Street: 2016. 
73 Mounk Y. The People vs. Democracy: Why Our Freedom Is in Danger and How to Save It. Cambridge, Massachusetts ; London, England: : Harvard University Press 2018. 


\section{WeB APPENDIX}

Web Appendix 1: Descriptive statistics.

Web Appendix 2: Bootstrapped analysis of the association between inequalities in political participation and health by dropping one country sequentially 
Web Appendix 1: Descriptive statistics

\begin{tabular}{|c|c|c|c|c|c|c|}
\hline Variable & Mean & Std. Dev. & Min & Max & Unit & Source \\
\hline $\begin{array}{l}\text { All-cause mortality, } \\
\text { male }^{1}\end{array}$ & 2.31 & 0.84 & 1.4 & 4.8 & Rate ratio & DEMETRIQ \\
\hline $\begin{array}{l}\text { All-cause mortality, } \\
\text { female }^{1}\end{array}$ & 1.85 & 0.47 & 1.3 & 3.2 & Rate ratio & DEMETRIQ \\
\hline $\begin{array}{l}\text { Difference in } \\
\text { voting }^{2}\end{array}$ & 17.02 & 6.43 & 4.55 & 29.36 & Percentage point & $\begin{array}{l}\text { European } \\
\text { Social Survey }\end{array}$ \\
\hline $\mathrm{GDP}^{3}$ & 239.24 & 151.16 & 35 & 581 & $\begin{array}{l}\text { Per capita (PPP } \\
\$ 100)\end{array}$ & EuroStat \\
\hline GINI & 29.05 & 3.91 & 23.7 & 35 & $\begin{array}{l}\text { Range: } 0-100,0= \\
\text { equality }\end{array}$ & EuroStat \\
\hline $\begin{array}{l}\text { Social protection } \\
\text { spending } 4\end{array}$ & 65.71 & 40.74 & 9.81 & 129.86 & Per capita & Eurostat \\
\hline $\begin{array}{l}\text { Post-communist } \\
\text { country }\end{array}$ & 0.29 & - & 0 & 1 & $\begin{array}{l}1= \\
\text { post-communist }\end{array}$ & Various \\
\hline $\begin{array}{l}\text { Total health } \\
\text { spending }\end{array}$ & 6.05 & 1.41 & 2 & 7.6 & $\%$ of GDP & EuroStat \\
\hline $\begin{array}{l}\text { Difference in risk of } \\
\text { poverty }\end{array}$ & 22.95 & 7.84 & 8.6 & 36.4 & Percentage point & EuroStat \\
\hline $\begin{array}{l}\text { Difference in } \\
\text { smoking rates, } \\
\text { male }^{6}\end{array}$ & -11.34 & 6.47 & -25.2 & -0.6 & Percentage point & EuroStat \\
\hline $\begin{array}{l}\text { Difference in } \\
\text { smoking rates, } \\
\text { female }^{6}\end{array}$ & -4.31 & 6.55 & -13.5 & 5.9 & Percentage point & EuroStat \\
\hline Population size & 19.96 & 23.05 & 0.52 & 63.29 & $\begin{array}{l}\text { Per } 1,000,000 \\
\text { people }\end{array}$ & EuroStat \\
\hline
\end{tabular}

Notes: 1. Rate ratio by low and high education; 2. Percentage point difference in people who voted in last election by education; 3. GDP is adjusted for purchasing power and inflation; 4. Social protection spending is adjusted for purchasing power and inflation; 5. Percentage point difference in risk of poverty by high and low education; 6. Percentage point difference in current smokers by high and low education. Latest available data is used for health inequalities, most of which comes from the mid-2000s. Data on voting comes from wave 4 of the European Social Survey which was conducted between 2007 and 2008. Data on GDP, GINI, Social Protection spending, Total Health spending, and inequalities in poverty come from 2008. Data on smoking come from 2014. 
Web Appendix 2: Bootstrapped analysis of the association between inequalities in political participation and health by dropping one country sequentially

A: Men

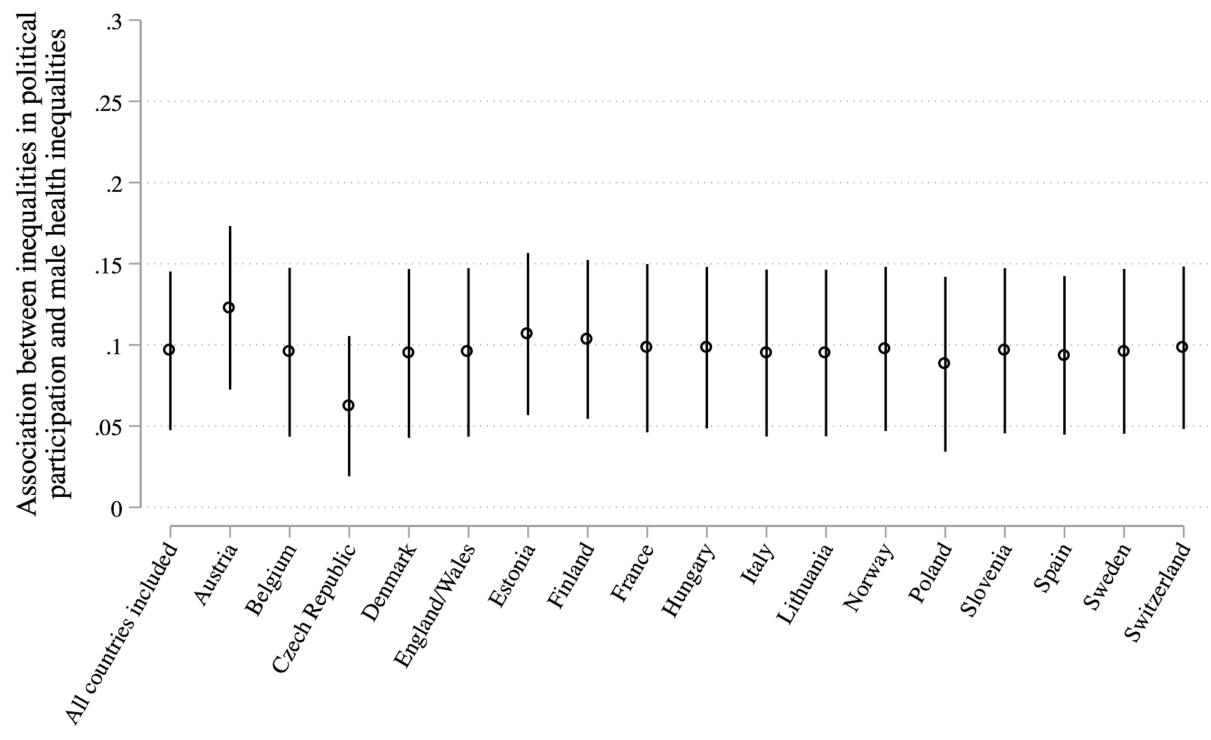

Which country has been dropped from the regression model

B: Women

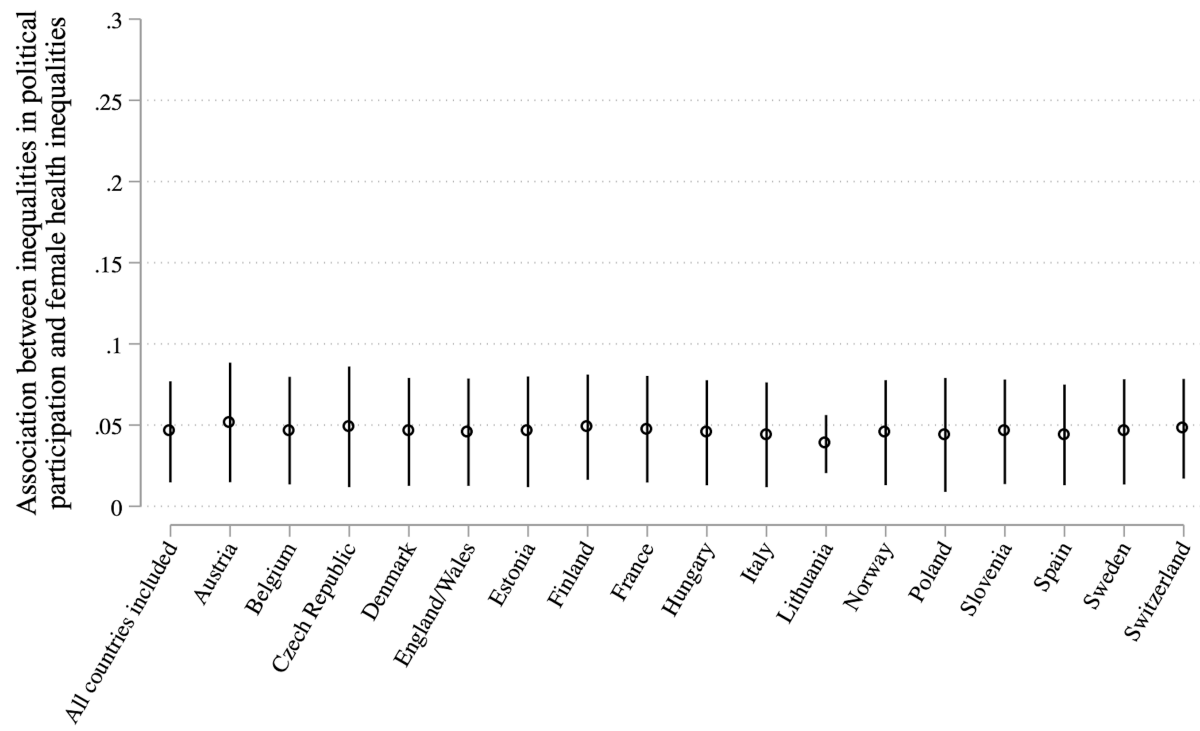

Which country has been dropped from the regression model

Notes: These models are just the raw correlation between inequalities in political participation and health inequalities for men and women. 